\title{
Short antimicrobial peptides as cosmetic ingredients to deter dermatological pathogens
}

\author{
Mohammad Rahnamaeian ${ }^{1}$ • Andreas Vilcinskas ${ }^{1,2}$ \\ Received: 9 June 2015 / Revised: 1 August 2015 / Accepted: 5 August 2015 / Published online: 26 August 2015 \\ (C) The Author(s) 2015. This article is published with open access at Springerlink.com
}

\begin{abstract}
Antimicrobial peptides (AMPs) are components of the innate immune system in many species of animals. Their diverse spectrum of activity against microbial pathogens, both as innate defense molecules and immunomodulators, makes them attractive candidates for the development of a new generation of antibiotics. Although the potential immunogenicity of AMPs means they are not suitable for injection and their susceptibility to digestive peptidases is likely to reduce their oral efficacy, they are ideal for topical formulations such as lotions, creams, shampoos, and wound dressings and could therefore be valuable products for the cosmetic industry. In this context, short AMPs ( $<20$ amino acids) lacking disulfide bonds combine optimal antimicrobial activity with inexpensive chemical synthesis and are therefore more compatible with large-scale production and the modifications required to ensure stability, low toxicity, and microbial specificity. Proofof-concept for the application of AMPs as novel antiinfectives has already been provided in clinical trials. This perspective considers the anti-infective properties of short AMPs lacking disulfide bonds, which are active against dermatologically important microflora. We consider the challenges that need to be addressed to facilitate the prophylactic application of AMPs in personal care products.
\end{abstract}

Andreas Vilcinskas

Andreas.Vilcinskas@agrar.uni-giessen.de

1 Fraunhofer Institute for Molecular Biology and Applied Ecology, Department of Bioresources, Winchester Strasse 2, 35394 Giessen, Germany

2 Institute for Phytopathology and Applied Zoology, Justus-Liebig-University of Giessen, Heinrich-Buff-Ring 26-32, 35392 Giessen, Germany
Keywords Anti-infective $\cdot$ Antimicrobial peptides $\cdot$ Cosmetic industry $\cdot$ Dermal pathogens $\cdot$ Prophylaxis $\cdot$ Skin diseases

\section{Introduction}

Animals are covered in protective layers of cells and their secretions, providing a semi-permeable environmental barrier colloquially described as "skin". In humans, the skin is the first line of defense against continuous assault by a diverse range of microbes, some of which are able to cause severe dermatological diseases, especially in immunocompromised patients (Table 1). The innate immune response in most animal species includes the synthesis of antimicrobial peptides (AMPs) that can kill microbes by contact, suppress their growth, or act as immunomodulators (Bolouri Moghaddam et al. 2015; Rahnamaeian et al. 2009; Vilcinskas 2011). Hundreds of AMPs have been discovered with overlapping activity spectra against different classes of pathogen (including viruses, bacteria and fungi), and this makes them attractive candidates for the development of novel antimicrobials. Because they are peptides, they are unlikely to be suitable for injection (due to potential immunogenicity) or oral administration (due to peptidase sensitivity) without significant modification (Wiesner and Vilcinskas 2010), leaving topical application as the one remaining option. Humans naturally produce AMPs in the skin, so the addition of further AMPs with broader activity could be developed as a therapeutic intervention for the treatment of skin diseases and also a prophylactic strategy in the cosmetic industry to deter pathogens and promote skin health. This could be realized in topical formulations such as ointments, lotions, shampoos, creams, or wound dressings targeting skin pathogens and avoiding the complexities of systemic anti-infectives (Table 2). 
Table 1 Dermatological diseases, corresponding pathogens and relevant AMPs

\begin{tabular}{|c|c|c|c|c|}
\hline Disease & Microbial agent & Region of infection & Active AMPs & Reference \\
\hline Folliculitis & Staphylococcus aureus & Hair follicles & $\begin{array}{l}\text { UBI } \\
\text { TsAP-2 } \\
\text { NRC-16 } \\
\text { Epinecidin } 4 \text { \& } 5 \text { \& } 6 \& 7 \& 8 \\
\text { PE1 \& PE2 } \\
\text { HM2 \& HM5 } \\
\text { Ranalexin } \\
\text { Plc-2 }\end{array}$ & $\begin{array}{l}\text { Brouwer et al. } 2006 \\
\text { Guo et al. } 2013 \\
\text { Gopal et al. } 2013 \\
\text { Lin et al. } 2013 \\
\text { Huang et al. } 2013 \\
\text { Park et al. } 2004 \\
\text { Aleinein et al. } 2013 \\
\text { Souza et al. } 2013\end{array}$ \\
\hline Hot tub folliculitis & Pseudomonas aeruginosa & Hair follicles & $\begin{array}{l}\text { Stylisin } 2 \\
\text { NRC-16 } \\
\text { PE1 \& PE2 } \\
\text { Plc-2 }\end{array}$ & $\begin{array}{l}\text { Dahiya \& Gautam, } 2010 \\
\text { Gopal et al. } 2013 \\
\text { Huang et al. } 2013 \\
\text { Souza et al. } 2013\end{array}$ \\
\hline Impetigo & $\begin{array}{l}\text { Staphylococcus aureus } \\
\text { Staphylococcus pyogenes }\end{array}$ & Skin & $\begin{array}{l}\text { See above } \\
\text { Ranalexin }\end{array}$ & $\begin{array}{l}\text { See above } \\
\text { Aleinein et al. } 2013\end{array}$ \\
\hline Dermatophytosis & $\begin{array}{l}\text { Microsporum audouinii } \\
\text { Microsporum gypseum }\end{array}$ & Skin & $\begin{array}{l}\text { Stylisin } 2 \\
\text { Tachyplesin III }\end{array}$ & $\begin{array}{l}\text { Dahiya \& Gautam, } 2010 \\
\text { Simonetti et al. } 2009\end{array}$ \\
\hline White piedra & Trichosporon beigelii & Hair & $\begin{array}{l}\text { HM2 \& HM5 } \\
\text { Rev-NIS }\end{array}$ & $\begin{array}{l}\text { Huang et al. } 2013 \\
\text { Lee \& Lee } 2009\end{array}$ \\
\hline Seborrheic dermatitis & Malassezia furfur & Scalp, face, torso & $\begin{array}{l}\text { P5 } \\
\text { Rev-NIS }\end{array}$ & $\begin{array}{l}\text { Ryu et al. } 2011 \\
\text { Lee \& Lee } 2009\end{array}$ \\
\hline Onychomycosis & Trichophyton rubrum & Nail & $\begin{array}{l}\text { Cryptocandin } \\
\text { Tachyplesin III }\end{array}$ & $\begin{array}{l}\text { Stobel et al. } 1999 \\
\text { Simonetti et al. } 2009\end{array}$ \\
\hline & Trichophyton mentagrophytes & Nail & $\begin{array}{l}\text { Stylisin } 2 \\
\text { A12-C } \\
\text { Cryptocandin } \\
\text { Tachyplesin III }\end{array}$ & $\begin{array}{l}\text { Dahiya \& Gautam } 2010 \\
\text { Gálvez et al. } 1993 \\
\text { Stobel et al. } 1999 \\
\text { Simonetti et al. } 2009\end{array}$ \\
\hline $\begin{array}{l}\text { Athlete's foot (tinea pedi) } \\
\text { Intertrigo }\end{array}$ & $\begin{array}{l}\text { Trichophyton rubrum } \\
\text { Candida albicans }\end{array}$ & $\begin{array}{l}\text { Foot } \\
\text { Body folds }\end{array}$ & $\begin{array}{l}\text { See above } \\
\text { Stylisin } 2 \\
\text { TsAP-2 } \\
\text { HM2 \& HM5 } \\
\text { Cryptocandin } \\
\text { Ranalexin } \\
\text { Rev-NIS }\end{array}$ & $\begin{array}{l}\text { See above } \\
\text { Dahiya \& Gautam } 2010 \\
\text { Guo et al. } 2013 \\
\text { Park et al. } 2004 \\
\text { Stobel et al. } 1999 \\
\text { Aleinein et al. } 2013 \\
\text { Lee \& Lee } 2009\end{array}$ \\
\hline Jock itch/tinea cruris & Trichophyton rubrum & Groin & See above & See above \\
\hline Ringworm - tinea corporis & Trichophyton mentagrophytes & Glabrous skin & $\begin{array}{l}\text { See above } \\
\text { A12-C } \\
\text { Tachyplesin III } \\
\text { See above }\end{array}$ & $\begin{array}{l}\text { See above } \\
\text { Gálvez et al. } 1993 \\
\text { Simonetti et al. } 2009 \\
\text { See above }\end{array}$ \\
\hline Tinea versicolor & Malassezia furfur & $\begin{array}{l}\text { Trunk and proximal } \\
\text { extremities }\end{array}$ & See above & See above \\
\hline $\begin{array}{l}\text { Atopic eczema and } \\
\text { seborrhoeic eczema, } \\
\text { dandruff }\end{array}$ & Malassezia sympodialis & Skin & $\begin{array}{l}\text { Arg } 9 \\
\text { Tat }(47-57) \\
\text { Pnetratin } \\
\text { pVEC } \\
\text { Scrambled pVEC }\end{array}$ & Holm et al. 2012 \\
\hline Tinea barbae & Trichophyton mentagrophytes & Hair and beard & See above & See above \\
\hline
\end{tabular}




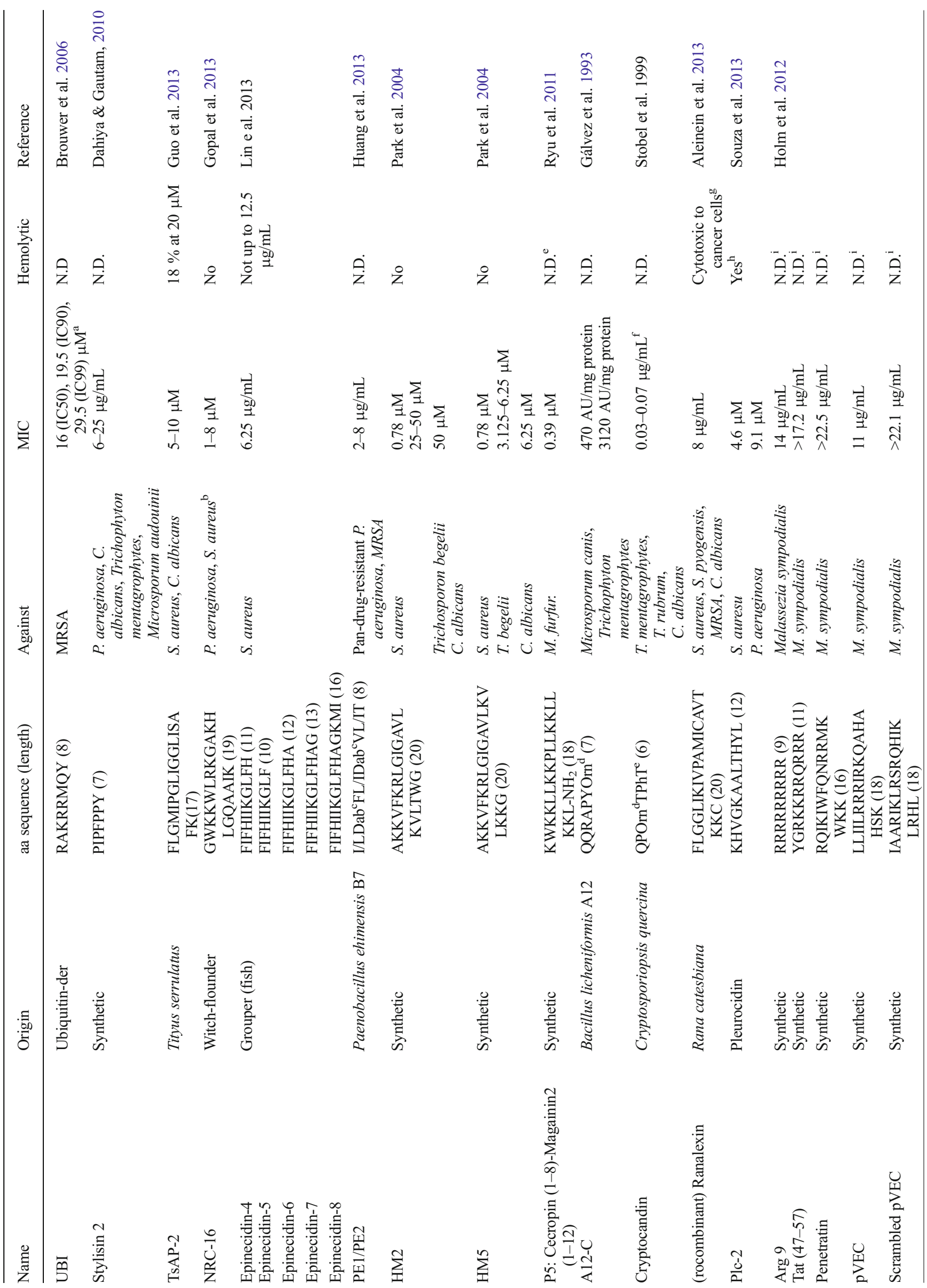


The production of AMPs as cosmetic ingredients would require large-scale production, placing the focus on properties such as peptide length and structure. AMPs longer than 20 amino acids would be too expensive for routine chemical synthesis, and the requirement for disulfide bonds would introduce additional folding steps that would also increase the costs of production. Short AMPs are less immunogenic and would therefore be less likely to trigger allergies (Dhiraj et al. 2006), and they would be easier to modify to increase stability, reduce toxicity, or engineer microbial specificity. It is worthy to note that the selection of an appropriate formulation for AMPbased topical products has a substantial impact on their efficacy (Trotti et al. 2004; Kollef et al. 2006; van Saene et al. 2007) as shown for the treatment of oral mucositis, in which a mucosal-adhesive paste is superior to a mouthwash (van Saene et al. 2007).

In this perspective, we discuss the antimicrobial properties of short AMPs (fewer than 20 residues, and no disulfide bonds) that are active against dermatologically relevant pathogens as cosmetic ingredients. We discuss the requirements that must be met for their prophylactic application in personal care products. However, we do not include the development of AMPs targeting Acne vulgaris, which has been comprehensively discussed in other articles (Fisk et al. 2014; Howard 2014; Cresce et al. 2014; Bartlett et al. 2014; Rocha et al. 2014; Zouboulis 2014).

\section{Naturally occurring AMPs in human skin}

Like other animals, humans naturally produce AMPs in the skin to deter pathogens. These self-peptides are suitable candidates for development as cosmetic ingredients because they would be the least likely to cause offtarget effects. Human skin AMPs include $\beta$-defensin (hBD-2), RNase7, and psoriasin, which are active against different ranges of skin pathogens. The antimicrobial activities of these peptides have been compared to the antibiotic fluconazole against the germinating conidia of Trichophyton rubrum, Trichophyton mentagrophytes, Epidermophyton floccosum, and Microsporum canis, revealing that all three AMPs significantly inhibited fungal growth although with variable efficacy depending on the AMP/pathogen combination. E. floccosum was suppressed by all three AMPs, whereas $M$. canis was only inhibited by psoriasin, but in the latter case, the inhibitory effect was greater than fluconazole (Fritz et al. 2012). Unfortunately, all three of the AMPs discussed above exceed 20 amino acids in length or contain disulfide bonds, which would increase the complexity and expense of large-scale production. 


\section{AMP-derived core fragments and their activity against skin pathogens}

Although natural human AMPs may be too long or complex for chemical synthesis, the entire AMP might not be required because the antimicrobial activity resolves to a smaller essential motif. This shorter derivative might show the same efficacy as the parent peptide but would be easier to synthesize. Several reports describe the engineering of AMPs to retain or even improve their efficacy while reducing their length as much as possible. One example is UBI, an eight-residue synthetic peptide representing residues $31-38$ of the 59-residue full-length AMP ubiquicidin, which retains full activity against methicillin resistant Staphylococcus aureus (Brouwer et al. 2006). Likewise, Lin et al. (2013) synthesized a series of truncated AMPs (anti-lipopolysaccharide factor from shrimp, epinecidin from grouper, and pardaxin from Pardachirus marmoratus) to look for shorter stretches of sequences that increase antimicrobial potency. As a result, epinecidin- 8 and pardaxin- 6 showed a broad range of activity against both Gram-positive and Gram-negative bacteria, with no induction of hemolysis. The same is true for Plc-2 which is a 12-residue C-terminal fragment of pleurocidin and the smallest fragment that retains the antimicrobial potency of the original peptide. Based on MIC values determined in vitro with low-ionicstrength medium, Plc-2 was active against $S$. aureus, Escherichia coli, and Pseudomonas aeruginosa but not against Enterococcus faecalis. The antifungal activity of the synthetic peptides against plant pathogens such as Fusarium oxysporum and Colletotrichum sp. were shown to be mediated by the lysis of organelle membranes (Souza et al. 2013).

\section{Engineering of AMPs to maximize antimicrobial activity and minimize hemolytic effect}

One concern regarding AMPs is their possible hemolytic effects at higher concentrations, which necessitates their targeted engineering to (i) improve their antimicrobial activity and (ii) reduce their hemolytic effects. Generally, an increase in positive charge increases the antimicrobial activity whereas an increase in hydrophobicity causes a hemolytic effect (Park et al. 2004). The configurational stereochemistry ( $D$ or L enantiomers) of specific amino acids may also affect hemolytic activity (Roy et al. 2002). In an attempt to trim AMPs by Lyssubstitution to improve their net charge, Park et al. (2004) produced the peptides HM2 and HM5, which showed antimicrobial activity against $S$. aureus, Trichospora beigelii and Candida albicans but no hemolytic activity in the range of $0.78-50 \mu \mathrm{M}$. In another study, Guo et al. (2013) tested two 17-mer amidated linear peptides (TsAP-1 and TsAP-2) isolated from the Brazilian yellow scorpion (Tityus serrulatus) and found they have distinct antimicrobial properties. TsAP-1 was less active than TsAP-2 against E. coli, S. aureus, and C. albicans with minimal inhibitory concentrations (MICs) of $120-160 \mu \mathrm{M}$ and hemolytic activity of $6.48 \%$ at $160 \mu \mathrm{M}$, whereas TsAP-2 showed potent activity against S. aureus $(\mathrm{MIC}=5 \mu \mathrm{M})$ and $C$. albicans $(\mathrm{MIC}=10 \mu \mathrm{M})$ with almost no hemolytic activity at $\leq 15 \mu \mathrm{M}$ but strong hemolytic activity thereafter. The replacement of four neutral amino acid residues in each peptide with lysine residues had a dramatic effect on their antimicrobial and hemolytic activities, particularly those of TsAP-1. The MIC values for the enhanced cationic analog (TsAP-S1) fell to $2.5 \mu \mathrm{M}$ for $S$. aureus and C. albicans and $5 \mu \mathrm{M}$ for E. coli, but the hemolytic activity increased to a maximum of $28 \%$ at $5 \mu \mathrm{M}$. The same lysine residue substitutions in TsAP-2 reduced its MIC against $E$. coli from $>320$ to $5 \mu \mathrm{M}$, but the hemolytic activity remained as high as TsAP-S1 (Guo et al. 2013).

\section{AMPs promising for the skin infections and atopic eczema}

C. albicans can cause skin infections and atopic eczema, characterized by the accumulation of neutrophils culminating in inflammatory responses and the secretion of enzymatic proteins. High-molecular-weight kininogen (HK) then triggers the formation and release of AMPs to interfere with the establishment of pathogenesis. Highly potent antifungal peptide fragments are produced via the proteolytic degradation of HK (Sonesson et al. 2011). Lipophilic yeasts of the genus Malassezia cause seborrheic dermatitis, resulting in the colonization of infected skin by Malassezia furfur, Malassezia globosa, Malassezia restricta, Malassezia slooffiae, Malassezia sympodialis, or Malassezia obobtusa (Nakabayashi et al. 2000). Especially, M. furfur causes several recalcitrant skin infections such as Tinia versicolor, seborrheic dermatitis and folliculitis. Pro-inflammatory cytokines produced at infected sites by keratinocytes then induce the inflammatory response, and saturated fatty acids released by yeast lipases stimulate the proliferation of yeast cells (Bukvić Mokos et al. 2012). Current therapeutic approaches involve topical formulations containing antifungal and antiinflammatory agents, except severe and recalcitrant cases which require systemic intervention. In the majority of cases, the first choice treatment is topical azole-type antifungal agents.

Recalcitrant skin infections caused by M. furfur are commonly treated with ketoconazole and/or itraconazole. However, certain AMPs are active against $M$. furfur, including cathelicidin (López-García et al. 2006). The infection of human keratinocytes with $M$. furfur also upregulates endogenous hBD-2 (Donnarumma et al. 2004). The antifungal and antiinflammatory effects of cecropin A(1-8)-magainin 2(1-12) hybrid peptide analog P5 against $M$. furfur were reported by Ryu 
et al. (2011). The MIC of P5 against $M$. furfur was $0.39 \mu \mathrm{M}$, 3-4 times higher than ketoconazole and itraconazole. From the mechanistic point of view, expression of IL-8 and Toll-like receptor 2, the activation of NF-kB, and the release of intracellular calcium in $M$. furfur-infected human keratinocytes were strongly attenuated by treatment with P5. Rev-NIS (nuclear entry inhibitory signal peptide of Rev protein), which is a 10-residue derivative of HIV-1 Rev protein also acts against M. furfur with MIC value of $20 \mu \mathrm{M}$ (Lee and Lee 2009).

\section{Microorganisms-derived AMPs active against dermal pathogens}

Fungal AMPs also show promising antimicrobial activity. The acidic hydrophilic heat-stable $0.77 \mathrm{kD}$ peptide A12-C from Bacillus licheniformis (Glu-Glu-Arg-Ala-Pro-Tyr-Orn) has been shown to inhibit cell growth and hyphal proliferation in Mucor plumbeus, Mucor mucedo, and the human dermal pathogens M. canis and T. mentagrophytes (Gálvez et al. 1993). A12-C is resistant to the proteolytic enzymes pronase, trypsin, and proteinase $\mathrm{K}$. As well, cryptocandin A is an aromatic lipopeptide antifungal agent isolated from the endophytic fungus Cryptosporiopsis cf. quercina, which shows antifungal activity against $T$. mentagrophytes and $T$. rubrum with plate MIC values of $0.035-0.070 \mu \mathrm{g} \mathrm{m}^{-1}$ (Strobel et al. 1999). A plate MIC value of $0.035 \mu \mathrm{g} \mathrm{ml}^{-1}$ was recorded against $C$. albicans, making this peptide and its chemical derivatives echinocandin and pneumocandin promising candidate therapeutics particularly for the control of human nail and skin diseases such onychomycosis, tinea pedi, tinea cruris, tinea corporis, and tinea barbea.

Recently, Huang et al. (2013) reported two active compounds (PE1 and PE2) isolated from Paenibacillus ehimensis B7, which are active against clinical isolates of $E$. coli, pandrug-resistant $P$. aeruginosa, and methicillin-resistant S. aureus.

\section{Insect-derived AMPs}

Insects represent the most diverse group of organism on earth. Their biodiversity at the species level is also reflected by their diversity of AMPs. The evolutionary success of insects can at least in part be attributed to their innate immune systems which display a remarkable plasticity in terms of functional shifts, diversification, or loss of genes encoding AMPs (Vilcinskas 2013). The highest number of AMPs in a single organism, which is more than 50 different AMPs, has been found in the invasive ladybird Harmonia axyridis (Vilcinskas et al. 2013). Insect-derived AMPs have been suggested for the development of novel anti-infectives (Ratcliffe et al. 2011; Vilcinskas 2013; Yi et al. 2014). Of particular interest for the development of directly applicable peptides against skin pathogens are AMPs from medicinal maggots of the green bottle fly Lucilia sericata. Their secretions cause remarkable therapeutic effects even on chronic and nonhealing wounds which include the removal of necrotic tissue (debridement), the acceleration of wound healing and wound disinfection (Sherman 2014). The value of medicinal maggots which are also known as wound maggots in traditional medicine has inspired researchers to identify AMPs produced and secreted by the maggots. A defensin-like peptide named lucifensin displays activity against Gram-positive bacteria (Cerovsky et al. 2010). Another novel peptide from $L$. sericata which displays exclusive antifungal activities has been named lucimycin (Pöppel et al. 2014). However, both AMPs are too large to be developed as short peptidic anti-infectives. Experimental screening for immune-inducible AMPs using suppression subtractive hybridization (Altincicek and Vilcinskas 2009) and nextgeneration sequencing of the transcriptome from immunechallenged $L$. sericata maggots identified 47 genes encoding putative AMPs including short peptides such as cecropins, diptericins, proline-rich peptides, and sarcotoxins. Twenty three of them were produced as synthetic analogs among which some exhibited activity against a broad spectrum of microbial pathogens (Pöppel et al. 2015). The easy-tosynthesize Lucilia-derived AMPs with potent antimicrobial activity are presently produced in bulk to enable their development both as constituents in hydrogels for wound healing and as cosmetic ingredients to deter dermatological pathogens.

\section{Skin pathogens can modulate the efficacy of AMPs}

C. albicans secretes a large glycofragment of the Msb2 surface protein $\left(\mathrm{Msb}^{*}\right)$ into its immediate environment as a protective decoy for the human AMPs LL-37 and histatin-5 (Swidergall et al. 2013). Likewise, Msb2* can also interact with human defensins thereby shielding $C$. albicans from their antifungal properties. It also inactivates the lipopeptide antibiotic daptomycin, protecting S. aureus, Corynebacterium pseudodiphteriticum, and E. faecalis. The concurrent cultivation of $S$. aureus and wild-type C. albicans (but not the $m s b 2$ mutant) resulted in the cross-protection of the bacteria by $\mathrm{Msb2*}$ which attenuated the bactericidal activity of daptomycin and thus incapacitated an important reserve antibiotic (Swidergall et al. 2013).

Cationic AMPs often work by penetrating the bacterial cell membrane and altering its transmembrane potential (Rahnamaeian 2011). Accordingly, sense-response systems that perceive AMPs and induce adaptive reactions can increase bacterial persistence. In S. aureus, the LytSR twocomponent regulatory system may serve as a sensor of transmembrane potential. According to Yang et al. (2013), LytSR 
plays a key role in the adaptive response of $S$. aureus to membrane-stressing AMPs, perhaps by perceiving slight changes in transmembrane potential.

\section{Cationic AMPs are sensitive to $\mathrm{pH}$}

Walkenhorst et al. (2013) described a family of cationic AMPs with strong, broad-spectrum activity at neutral $\mathrm{pH}$ and low ionic strength. The efficacy of these peptides against an array of microbes varied linearly with $\mathrm{pH}$ for each subtype, i.e. they were far less effective against $C$. albicans and Gram-negative bacteria at high $\mathrm{pH}$ values, reflecting the decline in net positive charge. Interestingly, a reverse $\mathrm{pH}$ trend was observed for their activity against the Gram-positive bacterium $S$. aureus, probably reflecting the presence of charged molecules in the peptidoglycan layer of the cell wall. The buffer $\mathrm{pH}$ and ionic strength showed an additive effect on AMP activity (Walkenhorst et al. 2013).

\section{Multiple AMPs can interact to maximize their antimicrobial potency}

The synergy of AMPs and antibiotics has been frequently reported. For instance, Ranalexin is a cationic peptide 20 residues in length isolated from Rana catesbeiana, which is active against $S$. aureus, $S$. pyogenesis, methicillin-resistant $S$. aureus, and C. albicans with a MIC value of $8 \mu \mathrm{g} \mathrm{ml}^{-1}$ (Aleinein et al. 2013); however, when combined with polymyxin B or linezolid, the MIC value is reduced by $75 \%$ (Aleinein et al. 2014). As well, epinecidin-8 and pardaxin-6 work in synergy with streptomycin and kanamycin to increase their potency up to $75 \%$ against methicillin-resistant $S$. aureus (Lin et al. 2013). Nonetheless, the potentiation between naturally co-occurring AMPs has been almost neglected. We have recently shown that the concurrent application of multiple AMPs can increase the overall antimicrobial potency in a more than additive manner (Rahnamaeian et al. 2015; Pöppel et al. 2015). In nature, microbial challenge elicits a cocktail of AMPs in response (Rahnamaeian and Vilcinskas 2012; Vilcinskas et al. 2013). These AMPs usually have diverse modes of action so that they complement rather than replicate each other. For example, the insect AMPs abaecin and hymenoptaecin work cooperatively to inhibit the proliferation of E. coli at low MICs (Rahnamaeian et al. 2015). Abaecin shows no antimicrobial activity when presented alone because it needs to gain entry into the cell to interact with the bacterial chaperone DnaK, whereas hymenoptaecin is only active at high concentrations because its mechanism as a sole agent is based on the dose-dependent perforation of the bacterial membrane. However, when both AMPs are present together, hymenoptaecin creates pores that allow abaecin to access the

cell and bind to DnaK, and this in turn inhibits the bacterial mechanisms that repair membrane damage allowing hymenoptaecin to compromise the cell more rapidly. A similar synergistic activity has also been observed among particular AMPs produced and secreted by medicinal maggots L. sericata (Pöppel et al. 2015). Because the antimicrobial properties of AMPs can be resolved to shorter motifs, the synthesis of hybrid peptides encompassing the functional motifs of several AMPs could provide robust protection against microbial pathogens by combining the beneficial properties of multiple AMPs into one therapeutic entity.

\section{Organometallic derivatives of short AMPs}

The organometallic derivation of existing short AMPs has the potential to (i) increase the potency of AMPs and (ii) provide metal-specific modes of action that delay the acquisition of resistance by bacterial populations. The typical classes of organometallic compounds are metallocene, M-arene, M-carbonyl, and M-carbene (Fig. 1). The activity of ferrocenoylderivatized AMPs predominantly reflects the lipophilic properties of the organometallic fragment (Albada et al. 2013). The L-to-D substitution of amino acid residues in short lipidated AMPs can also produce diastereomeric peptides with optimized antimicrobial potency and reduced hemolytic activity (Albada et al. 2013). The structural diversity and potential catalytic properties of organometallic AMP derivatives and their availability for ligand exchange and redox reactions (Gasser and Metzler-Nolte 2012) may contribute to their development as cosmetic ingredients. Generally, transition metals of the second and third rows of the periodic table with closed electron shells, e.g., ruthenium $(\mathrm{Ru})$, osmium $(\mathrm{Os})$, and

A

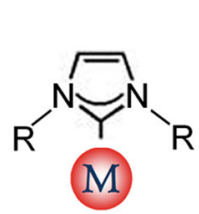

D
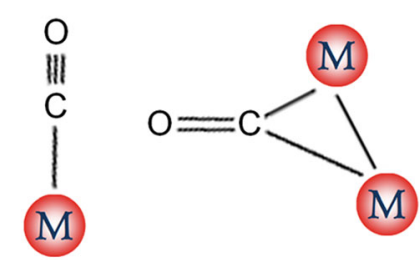

B

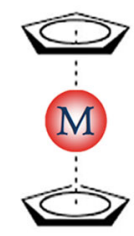

Fig. 1 Classic groups of the organometallics used in medicinal chemistry. a Metal-carbene. b Metallocene. c Metal-arene. d Metalcarbonyl (in different variants). $M$ indicates the metal element 
iridium (Ir), are the most proper cases to be recruited in medicinal inorganic chemistry (Gasser and Metzler-Nolte 2012).

\section{Conclusion}

Although AMPs have only been tested in a small number of clinical trials, there is adequate proof-of-concept to support their use as topical anti-infectives. Antimicrobials and their derivatives are unlikely to replace conventional antibiotics because they cannot be administered orally or by injection, but they are ideal for topical applications and could be used as pharmaceuticals to treat skin infections as well as cosmetic ingredients to deter skin pathogens and maintain skin health. The diverse spectrum of antimicrobial activities demonstrated by different AMPs, and the ease with which short AMPs can be synthesized and modified, make them promising candidates for the development of cosmetic products that deter dermatological pathogens.

Acknowledgments We acknowledge financial support provided by the Hessen State Ministry of Higher Education, Research and the Arts (HMWK) including a generous grant for the LOEWE research center "Insect Biotechnology and Bioresources" to A.V. The authors thank Richard M. Twyman for editing the manuscript.

Competing interests The author(s) declare that they have no competing interests.

Open Access This article is distributed under the terms of the Creative Commons Attribution 4.0 International License (http:// creativecommons.org/licenses/by/4.0/), which permits unrestricted use, distribution, and reproduction in any medium, provided you give appropriate credit to the original author(s) and the source, provide a link to the Creative Commons license, and indicate if changes were made.

\section{References}

Albada HB, Prochnow P, Bobersky S, Langklotz S, Bandow JE, MetzlerNolte N (2013) Short antibacterial peptides with significantly reduced hemolytic activity can be identified by a systematic L-to-D exchange scan of their amino acid residues. ACS Comb Sci 15(11): 585-592

Aleinein RA, Hamoud R, Schäfer H, Wink M (2013) Molecular cloning and expression of ranalexin, a bioactive antimicrobial peptide from Rana catesbeiana in Escherichia coli and assessments of its biological activities. Appl Microbiol Biotechnol 97(8):3535-3543

Aleinein RA, Schäfer H, Wink M (2014) Secretory ranalexin produced in recombinant Pichia pastoris exhibits additive or synergistic bactericidal activity when used in combination with polymyxin B or linezolid against multi-drug resistant bacteria. Biotechnol J 9(1):110-119

Altincicek B, Vilcinskas A (2009) Septic injury inducible genes in medicinal maggots of the blowfly Lucilia sericata. Insect Mol Biol 18: $119-125$

Bartlett KB, Davis SA, Feldman SR (2014) Tolerability of topical antimicrobials in treatment of acne vulgaris. J Drugs Dermatol 13(6): $658-662$
Bolouri Moghaddam MR, Vilcinskas A, Rahnamaeian M (2015) Cooperative interaction of antimicrobial peptides with the interrelated immune pathways in plants. Mol Plant Pathol. doi:10.1111/mpp. 12299

Brouwer CP, Bogaards SJ, Wulferink M, Velders MP, Welling MM (2006) Synthetic peptides derived from human antimicrobial peptide ubiquicidin accumulate at sites of infections and eradicate (multi-drug resistant) Staphylococcus aureus in mice. Peptides 27:2585-2591

Bukvić Mokos Z, Kralj M, Basta-Juzbašić A, Lakoš Jukić I (2012) Seborrheic dermatitis: an update. Acta Dermatovenerol Croat 20(2):98-104

Cerovsky V, Zdarek J, Fucik V, Monincova L, Voburka Z, Bem R (2010) Lucifensin, the long-sought antimicrobial factor of medicinal maggots of the blowfly Lucilia sericata. Cell Mol Life Sci 67:455-466

Cresce ND, Davis SA, Huang WW, Feldman SR (2014) The quality of life impact of acne and rosacea compared to other major medical conditions. J Drugs Dermatol 13(6):692-697

Dahiya R, Gautam H (2010) Total synthesis and antimicrobial activity of a natural cycloheptapeptide of marine origin. Mar Drugs 8(8):2384 2394. doi: $10.3390 / \mathrm{md} 8082384$

Dhiraj H, Young PR, Fairlie DP (2006) Current status of short peptides as vaccines. Med Chem 2:627-646

Donnarumma G, Paoletti I, Buommino E, Orlando M, Tufano MA, Baroni A (2004) Malassezia furfur induces the expression of betadefensin-2 in human keratinocytes in a protein kinase C-dependent manner. Arch Dermatol Res 295(11):474-481

Fisk WA, Lev-Tov HA, Sivamani RK (2014) Botanical and phytochemical therapy of acne: a systematic review. Phytother Res 28(8):11371152

Fritz P, Beck-Jendroschek V, Brasch J (2012) Inhibition of dermatophytes by the antimicrobial peptides human $\beta$-defensin-2, ribonuclease 7 and psoriasin. Med Mycol 50(6):579-584. doi: 10.3109/13693786. 2012.660203

Gálvez A, Maqueda M, Martínez-Bueno M, Lebbadi M, Valdivia E (1993) Isolation and physico-chemical characterization of an antifungal and antibacterial peptide produced by Bacillus licheniformis A12. Appl Microbiol Biotechnol 39(4-5):438-442

Gasser G, Metzler-Nolte N (2012) The potential of organometallic complexes in medicinal chemistry. Curr Opin Chem Biol 16(1-2):84-91

Gopal R, Lee JH, Kim YG, Kim MS, Seo CH, Park Y (2013) Antimicrobial, anti-biofilm activities and cell selectivity of the NRC-16 peptide derived from witch flounder, Glyptocephalus cynoglossus. Mar Drugs 11(6):1836-1852. doi:10.3390/md11061836

Guo X, Ma C, Du Q, Wei R, Wang L, Zhou M, Chen T, Shaw C (2013) Two peptides, TsAP-1 and TsAP-2, from the venom of the Brazilian yellow scorpion, Tityus serrulatus: evaluation of their antimicrobial and anticancer activities. Biochimie doi:pii: S0300-9084(13)00164 8

Holm T, Bruchmann J, Scheynius A, Langel U (2012) Cell-penetrating peptides as antifungals towards Malassezia sympodialis. Lett Appl Microbiol 54(1):39-44

Howard DM (2014) Adult acne: overview and case study. Nurse Pract 39(8):12-15

Huang Z, Hu Y, Shou L, Song M (2013) Isolation and partial characterization of cyclic lipopeptide antibiotics produced by Paenibacillus ehimensis B7. BMC Microbiol 13(1):87

Kollef M, Pittet D, Sanchez Garcia M, Chastre J, Fagon JY, Bonten M, Hyzy R, Fleming TR, Fuchs H, Bellm L, Mercat A, Mañez R, Martínez A, Eggimann P, Daguerre (2006) Prevention of pneumonia study (POPS-1) trial group. A randomized double-blind trial of iseganan in prevention of ventilator-associated pneumonia. Am J Respir Crit Care Med 173:91-97

Lee J, Lee DG (2009) Antifungal properties of a peptide derived from the signal peptide of the HIV-1 regulatory protein. Rev FEBS Lett 583(9):1544-1547 
Lin MC, Hui CF, Chen JY, Wu JL (2013) Truncated antimicrobial peptides from marine organisms retain anticancer activity and antibacterial activity against multidrug-resistant Staphylococcus aureus. Peptides 44:139-148. doi:10.1016/j.peptides.2013.04.004

López-García B, Lee PH, Gallo RL (2006) Expression and potential function of cathelicidin antimicrobial peptides in dermatophytosis and tinea versicolor. J Antimicrob Chemother 57(5):877-882

Nakabayashi A, Sei Y, Gulliot J (2000) Identification of Malassezia species isolated from patients with seborrheic dermatitis, atopic dermatitis, pityriasis versicolor and normal subjects. Med Mycol 38:337341

Park Y, Kim HN, Park SN, Jang SH, Choi CH, Lim HT, Hahm KS (2004) Design of novel analogues with potent antibiotic activity based on the antimicrobial peptide, HP(2-9)-ME(1-12). Biotechnol Lett 26(6):493-498

Pöppel AK, Koch A, Kogel KH, Vogel H, Kollewe C, Wiesner J, Vilcinskas A (2014) Lucimycin, an antifungal peptide from the therapeutic maggot of the common green bottle fly Lucilia sericata. Biol Chem 395:649-656

Pöppel AK, Vogel H, Wiesner J, Vilcinskas A (2015) Antimicrobial peptides expressed in medicinal maggots of the blow fly Lucilia sericata show combinatorial activity against bacteria. Antimicrobial Agents Chemother 59:2508-2514

Rahnamaeian M (2011) Antimicrobial peptides: modes of mechanism, modulation of defense responses. Plant Signal Behav 6:1325-1332

Rahnamaeian M, Cytrynska M, Zdybicka-Barabas A, Dobslaff K, Wiesner J, Twyman RM, Zuchner T, Sadd BM, Regoes RR, Schmid-Hempel P, Vilcinskas A (2015) Insect antimicrobial peptides show potentiating functional interactions against Gramnegative bacteria. Proc Biol Sci 282(1806):20150293

Rahnamaeian M, Langen G, Imani J, Khalifa W, Altincicek B, von Wettstein D, Kogel KH, Vilcinskas A (2009) Insect peptide metchnikowin confers on barley a selective capacity for resistance to fungal ascomycetes pathogens. J Exp Bot 60(14):4105-4114

Rahnamaeian M, Vilcinskas A (2012) Defense gene expression is potentiated in transgenic barley expressing antifungal peptide metchnikowin throughout powdery mildew challenge. J Plant Res 125:115-124

Ratcliffe NA, Mello CB, Garcia ES, Butt TM, Azambuja P (2011) Insect natural products and processes: new treatments for human disease. Insect Biochem Mol Biol 41:747-769

Rocha MA, Costa CS, Bagatin E (2014) Acne vulgaris: an inflammatory disease even before the onset of clinical lesions. Inflamm Allergy Drug Targets 13(3):162-167

Roy S, Lombart HG, Lubell WD, Hancock RE, Farmer SW (2002) Exploring relationships between mimic configuration, peptide conformation and biological activity in indolizidin-2-one amino acid analogs of gramicidin S. J Pept Res 60(4):198-214

Ryu S, Choi SY, Acharya S, Chun YJ, Gurley C, Park Y, Armstrong CA, Song PI, Kim BJ (2011) Antimicrobial and anti-inflammatory effects of cecropin A(1-8)-Magainin2(1-12) hybrid peptide analog p5 against Malassezia furfur infection in human keratinocytes. J Invest Dermatol 131(8):1677-1683

Sherman RA (2014) Mechanisms of maggot-induced wound healing: what do we know, and where do we go from Here? Evid Based Complement Alternat Med. doi:10.1155/2014/592419
Simonetti O, Ganzetti G, Arzeni D, Campanati A, Marconi B, Silvestri C, Cirioni O, Gabrielli E, Lenci I, Kamysz W, Kamysz E, Giacometti A, Scalise G, Barchiesi F, Offidani A (2009) In vitro activity of tachyplesin III alone and in combination with terbinafine against clinical isolates of dermatophytes. Peptides 30(10):1794-1797. doi:10.1016/j.peptides.2009.06.033

Sonesson A, Nordahl EA, Malmsten M, Schmidtchen A (2011) Antifungal activities of peptides derived from domain 5 of highmolecular-weight kininogen. Int J Pept 2011:761037

Souza AL, Díaz-Dellavalle P, Cabrera A, Larrañaga P, Dalla-Rizza M, De-Simone SG (2013) Antimicrobial activity of pleurocidin is retained in Plc-2, a C-terminal 12-amino acid fragment. Peptides 45:78-84. doi:10.1016/j.peptides.2013.03.030

Strobel GA, Miller RV, Martinez-Miller C, Condron MM, Teplow DB, Hess WM (1999) Cryptocandin, a potent antimycotic from the endophytic fungus Cryptosporiopsis cf. quercina. Microbiology 145(Pt 8):1919-1926

Swidergall M, Ernst AM, Ernst JF (2013) Candida albicans mucin Msb2 is a broad-range protectant against antimicrobial peptides. Antimicrob Agents Chemother 57(8):3917-3922. doi:10.1128/ AAC.00862-13

Trotti A, Garden A, Warde P, Symonds P, Langer C, Redman R, Pajak TF, Fleming TR, Henke M, Bourhis J, Rosenthal DI, Junor E, Cmelak A, Sheehan F, Pulliam J, Devitt-Risse P, Fuchs H, Chambers M, O'Sullivan B, Ang KK (2004) A multinational, randomized phase III trial of iseganan $\mathrm{HCl}$ oral solution for reducing the severity of oral mucositis in patients receiving radiotherapy for head-and-neck malignancy. Int J Radiat Oncol Biol Phys 58:674-681

van Saene H, van Saene J, Silvestri L, de la Cal M, Sarginson R, Zandstra D (2007) Iseganan failure due to the wrong pharmaceutical technology. Chest 132:1412

Vilcinskas A (2011) Anti-infective therapeutics from the lepidopteran model host Galleria mellonella. Curr Pharm Des 17:1240-1245

Vilcinskas A (2013) Evolutionary plasticity of insect immunity. J Insect Physiol 59(2):123-129

Vilcinskas A, Mukherjee K, Vogel H (2013) Expansion of the antimicrobial peptide repertoire in the invasive ladybird Harmonia axyridis. Proc Biol Sci 280(1750):20122113

Walkenhorst WF, Klein JW, Vo P, Wimley WC (2013) pH dependence of microbe sterilization by cationic antimicrobial peptides. Antimicrob Agents Chemother 57(7):3312-3320. doi:10.1128/AAC.00063-13

Wiesner J, Vilcinskas A (2010) Antimicrobial peptides, the ancient arm of the human immune system. Virulence 1(5):440-464

Yang SJ, Xiong YQ, Yeaman MR, Bayles KW, Abdelhady W, Bayer AS (2013) Role of LytSR two-component regulatory system in adaptation to cationic antimicrobial peptides in Staphylococcus aureus. Antimicrob Agents Chemother 57(8):3875-3882. doi:10.1128/ AAC.00412-13

Yi HY, Chowdhury M, Huang YD, Yu XQ (2014) Insect antimicrobial peptides and their applications. Appl Microbiol Biotechnol 98(13): 5807-5822

Zouboulis CC (2014) Acne as a chronic systemic disease. Clin Dermatol 32(3):389-396 